\title{
The potential of cellulose-degrading fungi at various peat maturities in Teluk Bakung Peat Area, Kubu Raya District, Indonesia
}

\author{
SITI KHOTIMAH ${ }^{1,2, \bullet}$, SUHARJONO $^{1}$, TRI ARDYATI ${ }^{1}$, YULIA NURAINI $^{3}$ \\ ${ }^{1}$ Faculty of Mathematics and Natural Sciences, Universitas Tanjungpura. Jl. Prof. Dr. H. Hadari Nawawi, Pontianak 78124, West Kalimantan, Indonesia, \\ Tel.: +62-561-577963, •email: siti1990khotimah@gmail.com \\ ${ }^{2}$ Department of Biology, Faculty of Mathematics and Natural Sciences, Universitas Brawijaya. Jl. Veteran, Malang 65145, East Java, Indonesia \\ ${ }^{3}$ Department of Soil Science, Faculty of Agriculture, Universitas Brawijaya. Jl. Veteran, Malang 65145, East Java, Indonesia
}

Manuscript received: 16 October 2020. Revision accepted: 26 March 2021.

\begin{abstract}
Khotimah S, Suharjono, Ardyati T, Nuraini Y. 2021. The potential of cellulose-degrading fungi at various peat maturities in Teluk Bakung Peat Area, Kubu Raya District, Indonesia. Biodiversitas 22: 1981-1990. Fungi play important roles in degrading cellulose in the maturation process of peat. This study aimed to evaluate the potential of cellulose-degrading fungi at various peat maturities in the forest. Peat soil samples were collected from Teluk Bakung Village, Kubu Raya District, West Kalimantan using a random sampling method. Peat soil samples were obtained at six sampling sites in forests and palm oil plantations. The fungi were cultured by the pour plate method on 1\% CMC media. The cellulose-degrading fungi were determined based on a clear zone formation around the colony in CMC agar media. The cellulolytic fungal population in the fibric, hemic, and sapric peats of the secondary forest were $3.2 \times 10^{3}, 4.6 \times$ $10^{3}$, and $5.6 \times 10^{3} \mathrm{CFU} / \mathrm{g}$, respectively, whereas at fibric, hemic, and sapric-of the shrubs-were $5.6 \times 10^{4}, 3.9 \times 10^{5}$ and $4.7 \times 10^{4} \mathrm{CFU} / \mathrm{g}$, respectively. Among the 25 cellulolytic fungal isolates, 5 isolates (HS1.5, HS3.4.1, HB2.2, SS2.4.1, and SB2.5.1) showed high average clear zone diameter (21-28 mm). The HS3.4.1 and HS1.5 isolates had cellulase enzyme activity of 132.16 and $127.3 \mathrm{U} / \mathrm{mL}$, respectively. These isolates can grow and degrade cellulose at $30^{\circ} \mathrm{C}$ to $35^{\circ} \mathrm{C}$ and $\mathrm{pH}$ of $2,3,4$, and 5. The HS3.4.1 and HS1.5 isolate were closely related to Penicillium citrinum based on the phylogenetic tree analysis.
\end{abstract}

Keywords: Cellulase activity, fungi, ITS region, peat

Abbreviations: CMC: Carboxymethylcellulose; PDA: Potato Dextrose Agar; DNS: Dinitrosalicylic Acid, ITS: Internal Transcribed Spacer; PCR: Polymerase Chain Reaction

\section{INTRODUCTION}

One of the peatland forests in West Kalimantan Province is located in Teluk Bakung village, Ambawang Subdistrict, Kubu Raya District with an area of 10.139.909 ha, comprising of peat forests, mixed estate and plantations, palm oil plantations, and open land (shrubs) (Wahyunto et al. 2010). The peat in this area has a depth of $>300 \mathrm{~cm}$ with three-peat maturity levels: fibric, hemic, and sapric. To date, there are no studies on the role of microbes in overhauling the organic material in peat soils of this area.

Tropical peatlands have low mineral content, but high organic matter content $(>90 \%)$, low total $\mathrm{N}$ content, and high $\mathrm{C} / \mathrm{N}$ ratio resulting in unavailability of these elements to plants. The microelements content, especially $\mathrm{Cu}, \mathrm{B}$, and $\mathrm{Zn}$, is considerably low. Peat soils exhibit significantly high cation exchange capacity (CEC; 90-200 me/100 g), but considerably low base saturation (KB) (Wahyunto 2015). It causes a reduction in the availability of nutrients, especially $\mathrm{K}, \mathrm{Ca}$, and $\mathrm{Mg}$. The fertility of peat soils can be improved by introducing organic decomposing microbes.

Peat formation and maturation occur through three processes which are biological, physical, and chemical maturation. Soil microbe activity supports the biological maturation of peat. Bacteria and fungi degrade wood decay by cellulase enzyme activity. A higher peat maturity level usually associated with many species of decomposing fungi (Saragih 2009). Aspergillus sp. and Mucor sp. are found in fibric peat. Hemic peat usually has a high of Penicillium chrysogenum, Mucor sp., Penicillium digitatum, Curvularia sp., and Penicillium sp. Aspergillus sp., Fusarium sp., and P. chrysogenum are found in sapric peat (Saragih 2009).

Cellulose is the most abundant renewable biomass in nature, with $7.2 \times 10^{10}$ tons synthesized through photosynthesis annually. Cellulose is a homogeneous polysaccharide with the cellobiose unit linked by $\beta-1,4-$ glycosidic bonds (Voriskova and Baldrian 2013). Hydrolysis of cellulose to D-glucose requires endo-1,4- $\beta$ glucanase (EC 3.2.1.4), cellobiohydrolase (EC 3.2.1.91), and $\beta$-glucosidase (EC 3.2.1.21) (Zhang et al. 2014). Endo$1,4-\beta$-glucanase randomly cuts the cellulose chain, producing the cellulose end. Cellobiohydrolase acts on the cellulose chain from the reducing or non-reducing end, produces cellobiose. $\beta$-glucosidase hydrolyzes cellobiose and cello-oligosaccharides to form glucose (Kjoller and Struwe 1982). Due to the chemical structure complexity, natural cellulose is difficult to degrade. Moreover, cellulose is present with lignin and hemicellulose structures. In nature, cellulose was mainly degraded by microbial cellulase. Fungi are the primary decomposer microorganisms due to their ability to produce various 
extracellular enzymes. It efficiently decays the recalcitrant, that difficult to be decomposed by other organisms. Several previous studies reported the ability of fungi to degrade leaves under laboratory conditions (Kjoller and Struwe 1982; Osono 2005; Zhang et al. 2008; Osono et al. 2009; Baldrian et al. 2011; Zhang et al. 2014).

Cellulolytic fungi play important roles in the forest ecosystem, transforming cellulose from various plant materials using their secreted enzymes even in extreme environments. In industrial, fungi can be isolated easily, and different strains had been stored in appropriate subcultures (Bahrami et al. 2010; Kunitake and Kobayashi 2017). Peat soil consists of organic material derived from plants, and the soil structure undergoes several changes due to decomposition. Moreover, the degree of maturity of peat to fibric, hemic, and sapric peat is determined by the level of organic decomposed material, such as cellulose content. Each level of peat maturity is inhabited by a group of fungi that can degrade cellulose. In this study, we isolate indigenous cellulolytic fungi and determine their potential to degrade cellulose to accelerate the process of peat maturity and increase peat fertility.

\section{MATERIALS AND METHODS}

\section{Soil sampling}

The geographical location of Teluk Bakung Village is $0^{\circ} 20^{\prime} 43^{\prime \prime}$ latitude and $109^{\circ} 15^{\prime} 48^{\prime \prime}$ east longitude (Figure 1). The village's climatic conditions were as follows: average temperature $\left(27.1^{\circ} \mathrm{C}\right)$; average humidity $(86 \%)$; air pressure (1012.20 mb); wind speed (4 knots); rainfall (2991 mm).
Peat soil samples were taken at six sampling sites in the forest and palm oil plantation in Teluk Bakung Village, Ambawang Subdistrict, Kubu Raya District, West Kalimantan Province, Indonesia based on peat maturity level.

Peat soil samples were collected randomly. It was collected three samples from the same site, then mixed as composite samples. The grass was cleared from the ground surface of sampling sites. Soil samples were collected using cylinder drill with $3.2 \mathrm{~mm}$ of diameter. The peat soil samples were transferred to plastic bags and labeled with depth, date, and acquisition location (Agus et al. 2011). Peat soil characteristics were analyzed based on soil maturity, chemical constituents, and physical structure. Soil chemicals were performed by determining $\mathrm{N}$ total levels, available $\mathrm{P}$, organic $\mathrm{C}, \mathrm{C} / \mathrm{N}$ ratio, $\mathrm{CEC}, \mathrm{pH}$, and temperature.

\section{Determination of soils peat maturity on sampling sites}

Approximately $100 \mathrm{~g}$ of peat soil was squeezed into the palm. The retained fibers in the palms were observed and classified according to the following criteria: sapric peat, which was decayed to a great extent that its original material could not be recognized; dark brown to black color; and the fibers retained in the palm are less than onethird of the initial amount. Hemic peat was half-ripe peat, some of its original materials are recognizable, brown in color, and the fiber content retained is one-third or twothirds of the initial amount. Fibric peat is undisturbed peat, and the original material could be identified, brown, and the fibers retained in the palm were more than two-thirds of the initial amount (Sumawinata et al. 2015).
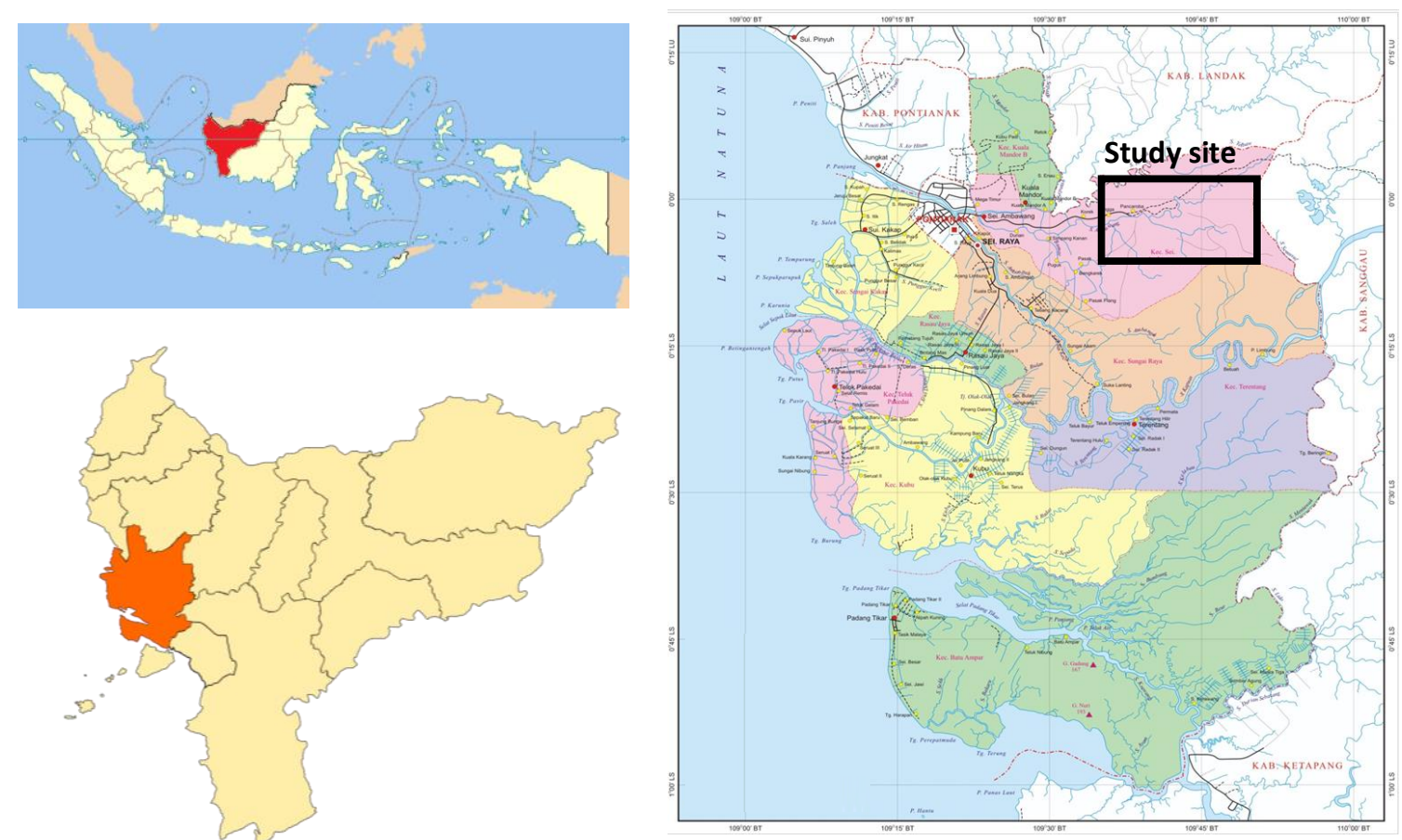

Figure 1. Study site in Teluk Bakung Village, Ambawang Subdistrict, Kubu Raya District, West Kalimantan Province, Indonesia 


\section{Determination of soils peat maturity in the laboratory}

Peat soil sample $(100 \mathrm{~g})$ was transferred into a $10 \mathrm{~mL}$ syringe. The syringe pump was pressed, and the volume of peat soil after the syringe pump cannot be compressed was recorded. Peat soils were sieved using a 100-mesh sieve. Filter was sprayed with water to rinse the fine peat. The remaining crude fiber was transferred into the syringe and compressed, and its volume was recorded. Fiber content was calculated by using the formula (Sumawinata et al. 2015).

\section{Fiber content $=(\mathrm{V} 2 / \mathrm{V} 1) \times 100 \%$}

Where:

V1 : volume of non-filtered peat

V2 : volume of filtered peat.

\section{Isolation and screening of cellulolytic fungi}

Peat soil (25 g) was suspended in an Erlenmeyer flask with $225 \mathrm{~mL}$ of $0.85 \%$ sterile saline solution. The suspension was diluted by serial dilution method in $0.85 \%$ saline solution to $10^{-6}$ dilution. One $\mathrm{mL}$ of an aliquot of each suspension was transferred onto CMC agar media (1\% carboxymethylcellulose powder, $1.5 \mathrm{~g}$ agar, and $100 \mathrm{~mL}$ mineral salt solution at $\mathrm{pH} 7.0(\mathrm{~g} / \mathrm{L})\left[(\mathrm{NH} 4)_{2} \mathrm{SO}_{4} \quad 2.0\right.$, $\mathrm{KH}_{2} \mathrm{PO}_{4}$ 2.7, $\mathrm{Na}_{2} \mathrm{HPO}_{4}$ 5.3, $\mathrm{NaCl} 0.2, \mathrm{MgSO}_{4}$ 0.2, and $\mathrm{CaCl}_{2}$ 0.05] (Arenas-Castro et al. 2016). The plates were incubated at $30^{\circ} \mathrm{C}-31^{\circ} \mathrm{C}$ for 7 days. After the incubation period, the growing colonies of fungi were purified by culturing on PDA media. The physical (fiber content, water content, and bulk density) and chemical (concentrations of $\mathrm{C}, \mathrm{N}, \mathrm{P}, \mathrm{K}$, microelements, CEC, cation content base, and $\mathrm{pH})$ properties of the peat soil was observed.

\section{Bioassay of cellulose-degrading fungi}

Semi-quantitative assay of cellulose-degrading fungi

Fungal colonies were streaked onto the surface of PDA media and incubated at room temperature for $12-18 \mathrm{~h}$. A monospore was inoculated into the CMC $1 \%$ agar media and incubated at $30^{\circ} \mathrm{C}$ for 7 days. The $\mathrm{CMC}$ media was flooded with $1 \%$ Congo Red reagent for $15 \mathrm{~min}$, followed by $\mathrm{NaOH} 1.0 \mathrm{M}$. The plates were incubated at room temperature for $10 \mathrm{~min}$. The clear zone around the fungi colony was measured using a digital caliper. The ratio of the clear zone diameter to the diameter of the colony was calculated (Behera et al. 2014). The fungi demonstrating the highest value of the clear zone index were chosen for further treatment.

\section{Screening of Endoglucanase activity}

The 7-days old of pure culture on PDA slant was suspended with $4 \mathrm{~mL}$ of $80 \%$ Tween 80 solution. The spore suspension was vortexed for $10 \mathrm{~min}$ and filtered using glass wool. The fungal spore suspension $(5 \mathrm{~mL})$ with a density of $10^{7}$ spores $/ \mathrm{mL}$ was inoculated into $95 \mathrm{~mL}$ of $1 \% \mathrm{CMC}$ broth media. The culture was incubated in a shaker incubator at $150 \mathrm{rpm}$ at room temperature for 7 days. The culture suspension was centrifuged at $10.000 \mathrm{rpm}, 4^{\circ} \mathrm{C}$ for 5 minutes. The supernatant contains crude extract of endoglucanase enzymes. Endoglucanase was determined by incubating the mixture of $200 \mu \mathrm{L}$ of cellulase enzyme and $1.0 \%$ of CMC in $1800-\mu \mathrm{L}$ buffer phosphate $(50 \mathrm{mM}$; $\mathrm{pH} 7.0$ ) at $50^{\circ} \mathrm{C}$ for $30 \mathrm{~min}$. Two $\mathrm{mL}$ of dinitrosalicylic acid (DNS) was added to the solution and heated in a water bath at $100^{\circ} \mathrm{C}$ for $5 \mathrm{~min}$. The sample was cooled at room temperature, and its absorbance was measured at $540 \mathrm{~nm}$. One unit of endoglucanase activity was the number of enzymes that can hydrolyze CMC and release $1 \mu \mathrm{g}$ glucose per $1 \mathrm{~min}$ reaction at $50^{\circ} \mathrm{C}$ (Yin et al. 2010). The selected isolates (high endonuclease activity, high spore viability, and does not inhibit other fungal isolates) were cultured in the $1 \% \mathrm{CMC}$ broth media at $\mathrm{pH}$ of $2,3,4$, and 5 and temperatures of $30^{\circ} \mathrm{C}, 35^{\circ} \mathrm{C}$, and $40^{\circ} \mathrm{C}$.

Cellulase activity $=\mathrm{C} / \mathrm{t} \times \mathrm{V}_{\mathrm{E}+\mathrm{S}} / \mathrm{V}_{\mathrm{E}},(2)$

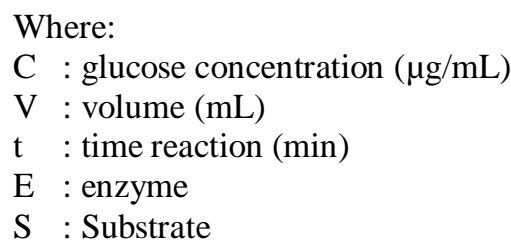

\section{Phylogenetic tree}

The selected isolates that can grow at various $\mathrm{pH}(2,3$, 4 , and 5) and high temperatures of $35{ }^{\circ} \mathrm{C}$ were identified based on the ITS sequence similarity. The 3- to 4-day-old fungal isolates were conducted to total DNA isolation using the Zymo-Spin ${ }^{\mathrm{TM}}$ kit. The suspension mixture was vortexed at maximum speed for $5 \mathrm{~min}$ for hyphae lysis. It was followed by centrifugation on microcentrifuge at $10.000 \mathrm{~g}$ for $1 \mathrm{~min}$. The supernatant $(400 \mu \mathrm{L})$ was transferred into the Zymo-Spin TM III-F filter containing a collection tube and recentrifuged at $10.000 \mathrm{~g}$ for $1 \mathrm{~min}$.

Table 1. Composition of $50 \mu \mathrm{L}$ PCR mix

\begin{tabular}{lcl}
\hline Solution & Volume $(\boldsymbol{\mu L})$ & Concentration \\
\hline $\mathrm{ddH}_{2} \mathrm{O}$ & 19 & \\
GoTaq® Green Master Mix & 25 & $1 \mathrm{x}$ \\
Primer 1 f (ITS 4) & 2 & $10 \mathrm{pmol} / \mu \mathrm{L}$ \\
Primer 2 f (ITS 5) & 2 & $10 \mathrm{pmol} / \mu \mathrm{L}$ \\
DNA template & 2 & $27.2 \mathrm{ng} / \mu \mathrm{L}$ \\
\hline
\end{tabular}

Table 2. 16S rDNA PCR reaction program

\begin{tabular}{lccc}
\hline Step & Temp. $\left({ }^{\circ} \mathbf{C}\right)$ & Time (seconds) & Cycle \\
\hline Early denaturation & 95 & 300 & 1 \\
Denaturation & 95 & 30 & 35 \\
Annealing & 52 & 45 & 35 \\
Extension & 72 & 90 & 35 \\
Final extension & 72 & 300 & 1 \\
\hline
\end{tabular}


Filtrate collected in the tube added with $1,200 \mu \mathrm{L}$ genomic lysis buffer. $800 \mu \mathrm{L}$ of this mixture was transferred to the Zymo-Spin ${ }^{\mathrm{TM}}$ IIC column contain the collection tube and centrifuged at $10,000 \mathrm{~g}$ for $1 \mathrm{~min}$. The filtrate was removed, and the previous steps were repeated. Subsequently, $200 \mu \mathrm{L}$ DNA-prewash buffer was added to the Zymo-Spin ${ }^{\mathrm{TM}}$ IIC column containing a new set of collection tubes and centrifuged at $10,000 \mathrm{~g}$ for $1 \mathrm{~min}$. The collection tubes were replaced with sterile microtubes, followed by $50 \mu \mathrm{L}$ DNA elution buffer to the upper tube, which was recentrifuged at $10.000 \mathrm{~g}$ for $1 \mathrm{~min}$. The chromosomal DNA was verified using $0.8 \%$ agarose gel electrophoresis. The ITS region of chromosomal DNA was amplified using polymerase chain reaction (PCR) with ITS 4 (5'-TCCTCCGCTTATTGATATGC-3 ') and ITS 5 (5'GGAAGTAAAAGTCGTAACAAGG-3') as primers $\left(1^{\text {st }}\right.$ BASE 2015). The ITS region was amplified using the PCR mix in Table 1 and PCR program in Table 2. The amplicon of the ITS region was verified using $1.5 \%$ agarose gel electrophoresis.

The amplicon of ITS region was sequenced at the $1^{\text {st }}$ Base DNA Sequencing Service, Malaysia. The sequences of the ITS region of each fungal isolate were combined using Bioedit software. It was aligned with ITS sequence references at NCBI database to identify fungal species. The ITS sequences of potential fungal isolate and some reference sequences were aligned to construct a phylogenetic tree. The phylogenetic tree was constructed based on the Neighbor-Joining algorithm and the TamuraNei model using MEGA 6 software.

\section{Data analysis}

Physical, chemical, fungal abundance, enzyme activity data at $\mathrm{pH}$ and temperature optimization were analyzed using one-way ANOVA, followed by Tukey test, using the SPSS 16.0 program. Non-homogeneous data were analyzed using Brown-Forsythe with a p-value of 0.05 .

\section{RESULTS AND DISCUSSION}

\section{Physiochemical properties of peat soil}

Sampling sites for peat soil sampling consists of secondary forest areas and oil palm plantations. Oil palm plantation comprises dry peat as it is located some distance from the Kapuas river. This drainage aims to reduce high water content, create an unsaturated soil for plant root respiration, wash off some organic acids and increase peat decomposition (Tonks et al. 2017). The depth of peat forest areas was $>3 \mathrm{~m}$, and the level of peat maturity was determined based on the decomposition level of the plant material (Figure 2). Maturity level consists of three categories of fibric, hemic, and sapric peat.

The chemical characteristics of peat soils in Indonesia are highly diverse. It was determined based on mineral composition, thickness, types of peat composting plants, types of minerals on the substratum (at the bottom of the peat), and the level of peat decomposition. Peatlands in
West Kalimantan, especially in Kubu Raya District, is generally dominated by timber. Therefore, the composition of organic matter is mostly lignin, which typically exceeds $60 \%$ of the dry matter, and other components, such as cellulose, hemicellulose, and protein, generally do not exceed $11 \%$ (Schropfer et al. 2015).

There was no peat management in peatland in the secondary forest and shrub or peat that the felling feller had just opened. Therefore, the water content was similar. The average water content was $60.6 \%$ and classified as moderate. High water content causes the peat to become soft and has a low load-bearing power (Ritung et al. 2011). Bulk density (BD) in the two sampling locations did not differ between fibric, hemic, and sapric peat (about 0.15 $\mathrm{g} / \mathrm{cm}^{3}$ ) (Table 3). Fibric peat that is generally located in the lower layer has a BD of $0.1 \mathrm{~g} / \mathrm{cm}^{3}$. Palm oil plantation peat and ex-fire peat have a BD of $0.3 \mathrm{~g} / \mathrm{cm}^{3}$, whereas forest peat has a BD of $0.15 \mathrm{~g} / \mathrm{cm}^{3}$ (Nurulita et al. 2016). The total porosity in secondary forest peat and peat in scrub/oil palm ranges from 87 to $93 \%$. Peat has low bearing capacity because of the large pore space, resulting in low soil density and lightweight. Total porosity for fibric/hemic soils is $86 \%-91 \%$ (volume) and $88 \%-92 \%$ for hemic/sapric material, and the average is about $90 \%$ by volume (Wahyunto 2015). Intact fiber levels at the two sampling locations differed. Fibric peat has a high intact fiber content. The conductivity at the two sampling locations and the level of maturity of the fibric, hemic, and sapric peat were not significantly different (Table 3 ).

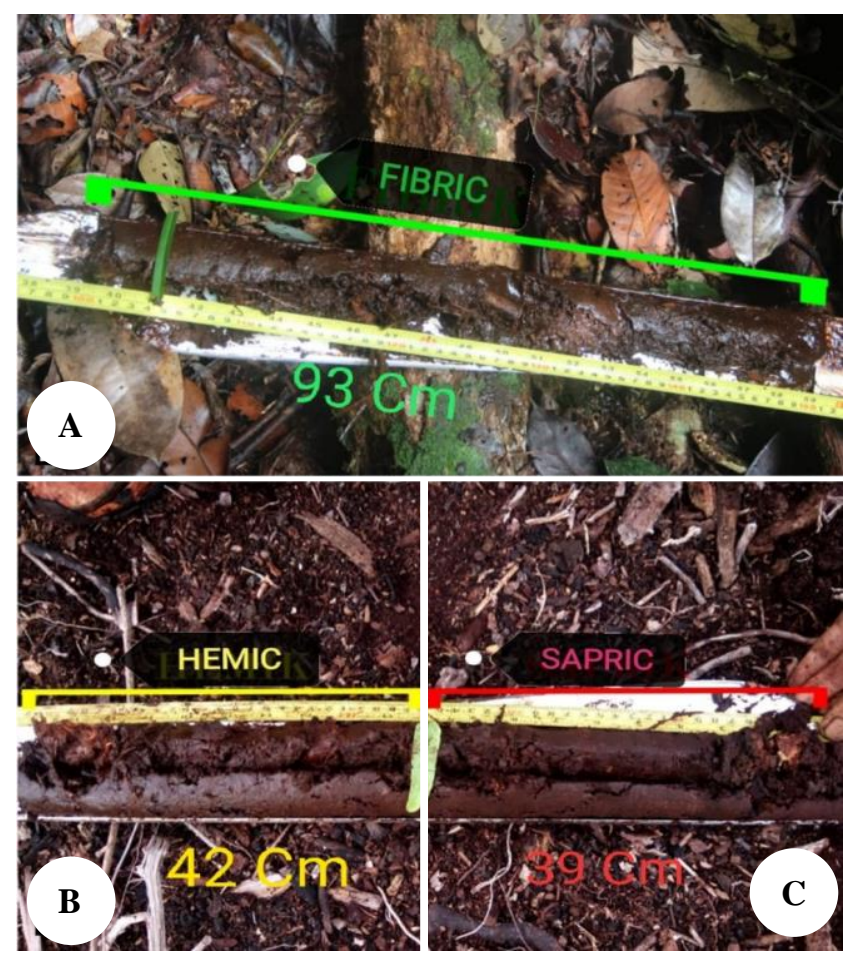

Figure 2. Vertically varying levels of peat maturity in peat soil profiles: A. Fibric, B. Hemic, C. Sapric 
Table 3. Physical properties of peat soils in forests and shrubs in Teluk Bakung Village, Kubu Raya District, West Kalimantan Province, Indonesia

\begin{tabular}{lllllll}
\hline \multicolumn{1}{c}{ Parameter } & \multicolumn{1}{c}{ Forest } & & & Scrub/oil palm \\
\cline { 2 - 6 } & Fibric & Hemic & Sapric & Fibric & Hemic & Sapric \\
\hline Bulk density $\left(\mathrm{g} / \mathrm{cm}^{3}\right)$ & $0.13 \pm 0.03 \mathrm{a}$ & $0.13 \pm 0.02 \mathrm{a}$ & $0.15 \pm 0.03 \mathrm{a}$ & $0.15 \pm 0.01 \mathrm{a}$ & $0.17 \pm 0.03 \mathrm{a}$ & $0.20 \pm 0.05 \mathrm{a}$ \\
Water content $\mathrm{pF}(\% \mathrm{vol})$ & $62.1 \pm 7.81 \mathrm{a}$ & $60.93 \pm 9.22 \mathrm{a}$ & $58.55 \pm 6.65 \mathrm{a}$ & $62.10 \pm 5.76 \mathrm{a}$ & $72.17 \pm 1.45 \mathrm{a}$ & $69.29 \pm 1.22 \mathrm{a}$ \\
Particle density $\left(\mathrm{g} / \mathrm{cm}^{3}\right)$ & $1.73 \pm 0.01 \mathrm{a}$ & $1.77 \pm 0.03 \mathrm{a}$ & $1.78 \pm 0.04 \mathrm{a}$ & $1.78 \pm 0.03 \mathrm{a}$ & $1.72 \pm 0.04 \mathrm{a}$ & $1.66 \pm 0.01 \mathrm{a}$ \\
Total porosity $(\%)$ & $92.51 \pm 1.54 \mathrm{~b}$ & $92.66 \pm 0.87 \mathrm{~b}$ & $91.19 \pm 1.72 \mathrm{ab}$ & $91.58 \pm 0.67 \mathrm{ab}$ & $89.47 \pm 1.69 \mathrm{ab}$ & $87.59 \pm 2.75 \mathrm{a}$ \\
Conductivity $(\mathrm{cm} / \mathrm{h})$ & $3.10 \pm 3.33 \mathrm{a}$ & $9.34 \pm 6.55 \mathrm{a}$ & $16.82 \pm 12.4 \mathrm{a}$ & $17.21 \pm 14.33 \mathrm{a}$ & $2.42 \pm 0.77 \mathrm{a}$ & $7.95 \pm 7.57 \mathrm{a}$ \\
Total fiber content $(\%)$ & $68.67 \pm 1.05 \mathrm{~cd}$ & $38.33 \pm 2.89 \mathrm{ab}$ & $28.33 \pm 2.89 \mathrm{a}$ & $71 \pm 10.15 \mathrm{~d}$ & $52.96 \pm 0.00 \mathrm{bc}$ & $25.66 \pm 5.13 \mathrm{a}$ \\
\hline
\end{tabular}

Table 4. Chemical properties of peat soils in forests and shrubs in Teluk Bakung Village, Kubu Raya District, West Kalimantan Province, Indonesia

\begin{tabular}{lllllll}
\hline \multirow{2}{*}{ Parameter } & \multicolumn{2}{c}{ Forest } & \multicolumn{2}{c}{ Scrub/oil palm } \\
\cline { 2 - 7 } & Fibric & Hemic & Sapric & Fibric & Hemic & Sapric \\
\hline $\mathrm{pH}$ & $3.05 \pm 0.091 \mathrm{a}$ & $3.16 \pm 0.11 \mathrm{a}$ & $2.95 \pm 0.135 \mathrm{a}$ & $3.0 \pm 0.092 \mathrm{a}$ & $2.96 \pm 0.090 \mathrm{a}$ & $3.00 \pm 0.066 \mathrm{a}$ \\
$\mathrm{C}-$ Organic $(\%)$ & $57.17 \pm 0.32 \mathrm{a}$ & $56.71 \pm 0.40 \mathrm{a}$ & $57.00 \pm 0.112 \mathrm{a}$ & $56.77 \pm 1.605 \mathrm{a}$ & $55.91 \pm 1.251 \mathrm{a}$ & $54.72 \pm 0.253 \mathrm{a}$ \\
$\mathrm{N}-\mathrm{Total}(\%)$ & $1.88 \pm 0.02 \mathrm{a}$ & $1.89 \pm 0.012 \mathrm{a}$ & $1.91 \pm 0.023 \mathrm{a}$ & $1.88 \pm 0.01 \mathrm{a}$ & $1.90 \pm 0.011 \mathrm{a}$ & $1.89 \pm 0.006 \mathrm{a}$ \\
$\mathrm{P}_{2} \mathrm{O}$ & $41.28 \pm 34.71 \mathrm{a}$ & $38.71 \pm 46.41 \mathrm{a}$ & $81.95 \pm 36.33 \mathrm{a}$ & $50.75 \pm 39.45 \mathrm{a}$ & $54.93 \pm 14.51 \mathrm{a}$ & $103.17 \pm 32.65 \mathrm{a}$ \\
$\mathrm{Ca}(\mathrm{cmol}(+) / \mathrm{kg})$ & $2.69 \pm 0.61 \mathrm{a}$ & $2.65 \pm 1.49 \mathrm{~b}$ & $3.55 \pm 2.414 \mathrm{ab}$ & $1.40 \pm 0.185 \mathrm{ab}$ & $1.14 \pm 0.410 \mathrm{a}$ & $1.30 \pm 0.513 \mathrm{a}$ \\
$\mathrm{Mg}(\mathrm{cmol}(+) / \mathrm{kg})$ & $0.88 \pm 0.45236 \mathrm{a}$ & $1.13 \pm 0.68 \mathrm{a}$ & $1.3 \pm 0.796 \mathrm{a}$ & $0.58 \pm 0.452 \mathrm{a}$ & $0.65 \pm 0.40 \mathrm{a}$ & $0.94 \pm 0.271 \mathrm{a}$ \\
$\mathrm{K}(\mathrm{cmol}(+) / \mathrm{kg})$ & $0.37 \pm 0.19 \mathrm{a}$ & $0.37 \pm 0.145 \mathrm{a}$ & $0.46 \pm 0.212 \mathrm{a}$ & $0.75 \pm 0.276 \mathrm{a}$ & $0.88 \pm 0.297 \mathrm{a}$ & $0.92 \pm 0.307 \mathrm{a}$ \\
$\mathrm{Na}(\mathrm{cmol}(+) / \mathrm{kg})$ & $0.61 \pm 0.335 \mathrm{ab}$ & $0.62 \pm 0.23 \mathrm{ab}$ & $0.67 \pm 0.427 \mathrm{a}$ & $1.36 \pm 0.469 \mathrm{ab}$ & $1.49 \pm 0.499 \mathrm{~b}$ & $1.58 \pm 0.508 \mathrm{~b}$ \\
$\mathrm{CEC}(\mathrm{cmol}(+) / \mathrm{kg})$ & $123.23 \pm 0.68 \mathrm{a}$ & $122.22 \pm 0.86 \mathrm{a}$ & $122.67 \pm 0.248 \mathrm{a}$ & $122.35 \pm 3.45 \mathrm{a}$ & $120.48 \pm 2.70 \mathrm{a}$ & $117.93 \pm 0.547 \mathrm{a}$ \\
\hline
\end{tabular}

Peat soils in secondary forests and palm oil plantations are highly acidic with $\mathrm{pH}$ of about 2-3 (Table 4). The $\mathrm{pH}$ of fibric, hemic, and sapric peat soils was not significantly different between the secondary forest and palm oil plantations. The acidity of peat soils is closely related to organic acid content, such as humic acid and fulvic acid (Schropfer et al. 2015). Secondary forest peat and shrubs used for palm oil plantations with different maturity levels have considerably high C-organic content (56\%) (Table 4). There was no significant effect on fibric, hemic, and sapric peat at the two sampling locations. The condition of drained peatlands can change because it creates an anaerobic atmosphere. These changes increase microorganisms' activity that degrade soil organic matter (Baldani et al. 2014; Elliott et al. 2015). Secondary forest peat and shrubs used for palm oil plantations have low Ntotal content $(1.88 \%)$, and there were no differences in fibric, hemic, and sapric peat (Table 4). This suggested pioneer microorganisms of soil organic matter and $\mathrm{N}$-cycle in the soil cannot work optimally. The activity of microorganisms is strongly influenced by soil $\mathrm{pH}$ conditions (Atekan et al. 2014). Secondary forest peat and shrubs used for palm oil plantations have a relatively high $\mathrm{P}_{2} \mathrm{O}_{5}$ content and no difference in the two sampling locations. The $\mathrm{P}_{2} \mathrm{O}_{5}$ content in sapric peat was higher than the fibric and hemic peat. It was due to the higher storage and supply of $\mathrm{P}$ at sapric peat soils than fibric soil. The phosphorus element $(\mathrm{P})$ in the peat soils was mostly found in the form of P-organic, which undergoes a process of mineralization into P-inorganic by microorganisms (Atekan et al. 2014). CEC on secondary forest peat and shrubs in locations was $121 \mathrm{cmol} / \mathrm{kg}$, and no difference at peat fibric, hemic, and sapric (Table 4). The peat CEC was high, whereas the base saturation (KB) was considerably low (Table 3). Peat in secondary forests and shrubs that would be planted with oil palms in the sampling area had a considerably low base cation content (Table 4). The peat thickness caused a low base content so that the soil becomes acidic (Kolli et al. 2016). The low content of Ca, $\mathrm{Mg}, \mathrm{K}$, and Na might be due to the peat condition, which is always saturated with water and only originated from the accumulation of organic matter, so there is no need to add mineral elements.

\section{The density of cellulolytic degrading fungi at peat soil}

The density of cellulolytic fungi in peat soils in secondary forests and shrubs planted with oil palm was significantly different. The population density of cellulolytic fungi in fibric, hemic, and sapric peat of secondary forests was not significantly different that is, were $3.2 \times 10^{3}, 4.6 \times 10^{3}$, and $5.6 \times 10^{3} \mathrm{CFU} / \mathrm{g}$, respectively. The fungi density was evenly distributed at various levels of peat maturity. The fungi density differs in fibric, hemic, and sapric peat of shrubs oil palms of $5.6 \times$ $10^{4}, 3.9 \times 10^{5}$, and $4.7 \times 10^{4} \mathrm{cfu} / \mathrm{g}$, respectively (Figure 3). In the hemic peat, the fungal density is higher than in fibric and sapric peat, but the density of cellulolytic fungi in fibric and sapric peat is not different. The density of cellulolytic fungi in shrubs/land planted with oil palm was higher than in secondary forests. It is possibly due to the drainage systems that enhance aerobic conditions. These conditions increase the activity of microorganisms to decompose peat. Drainage aims can reduce high water content, create an unsaturated state for breathing plant 
roots, wash off some organic acids and increase peat decomposition (Tonks et al. 2017). The majority of microbial decomposition of organic matter such as cellulose are bacteria and fungi. Fungi are the dominant organisms in hydrolyzing cellulose, especially in peat soils. Fungi secrete extracellular enzymes that are capable of decomposing organic matter. The activity of decomposing mold and organic matter determines the maturity level of the peat. The higher the level of maturity of the peat, the more types of decomposing molds are found.

\section{The potency of cellulolytic enzyme activity of fungi isolates}

Fifteen fungal species were isolated and selected to determine their ability to degrade cellulose. The SS2.4.1 and SB2.5.1 isolates had the highest clear zone diameter of 24.30 and $23.36 \mathrm{~mm}$, respectively (Figure 4). These fungal isolates were isolated from sapric and fibric peat in shrubs/palm oil (Figure 5). Cellulolytic fungi play important roles in the natural ecosystem to convert and break down cellulose.

\section{Endoglucanase activity of fungi}

Ten isolates of cellulose-degrading fungi were assayed for their cellulolytic enzyme activity. Three fungal isolates (HS3.4.1, HS1.5, and SS2.4.1.) had high cellulase activity, at 132, 127.3, and $121 \mathrm{U} / \mathrm{mL}$, respectively (Figure 6). These species were collected from sapric peat in secondary forests and shrubs. High levels of decomposition might be caused by active microorganisms that degrade cellulose. The level of peat maturity was determined by the level of decomposition of the organic matter. The cellulose hydrolyzing microorganisms are dominated by the prokaryotic group in bacteria, and the eukaryotic group in fungi (Lynd et al. 2002). Aerobic filamentous fungi produce extracellular non-composite cellulase systems (Lynd et al. 2002; Wilson 2011). The fungus produces an enzyme endo-1,4- $\beta$-D-glucanase decreases $\beta$-D-glucose oligomer to glucose and GH61 protein, which encourages cellulose decomposition of oxidative degradation of glucose polymers (Zhang et al. 2014). The $\beta$-glucosidase plays an important role in the biological conversion of cellulose to glucose (Doolotkeldieva and Bobusheva 2011).

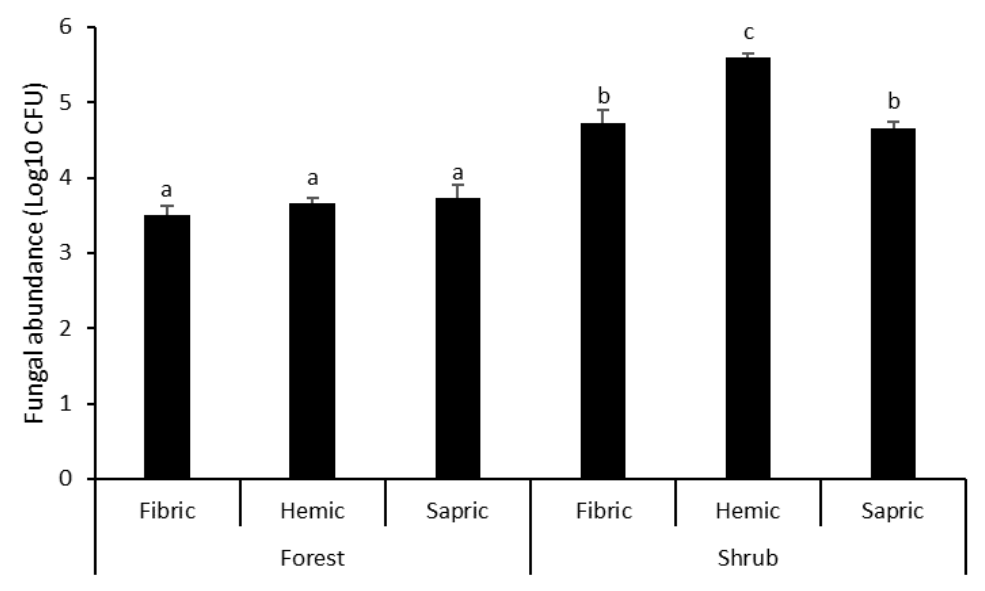

Figure 3. The abundance of cellulolytic fungi at fibric, hemic, and sapric peat in secondary forest and shrub/palm oil plantation

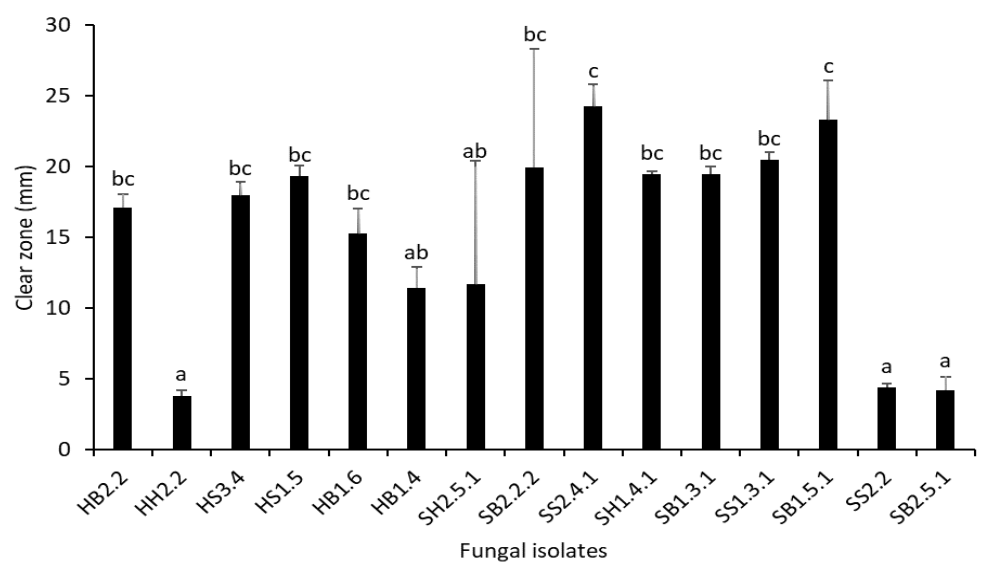

Figure 4. The diameter of the clear zone of the fungal isolates from peat soils indicates cellulolytic activity 

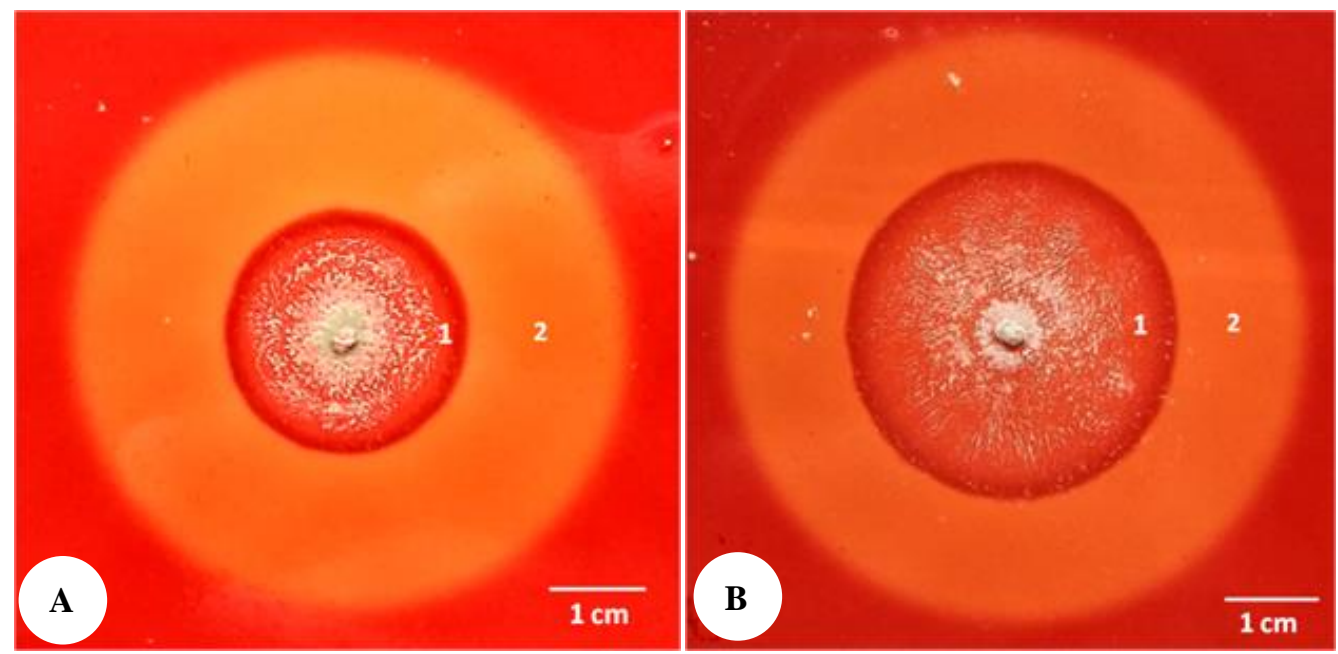

Figure 5. The clear zone around the fungal colony on $1 \%$ sodium carboxymethyl cellulose agar medium. A. SB2.5.1, B. SS2.4.1 isolate of fungi

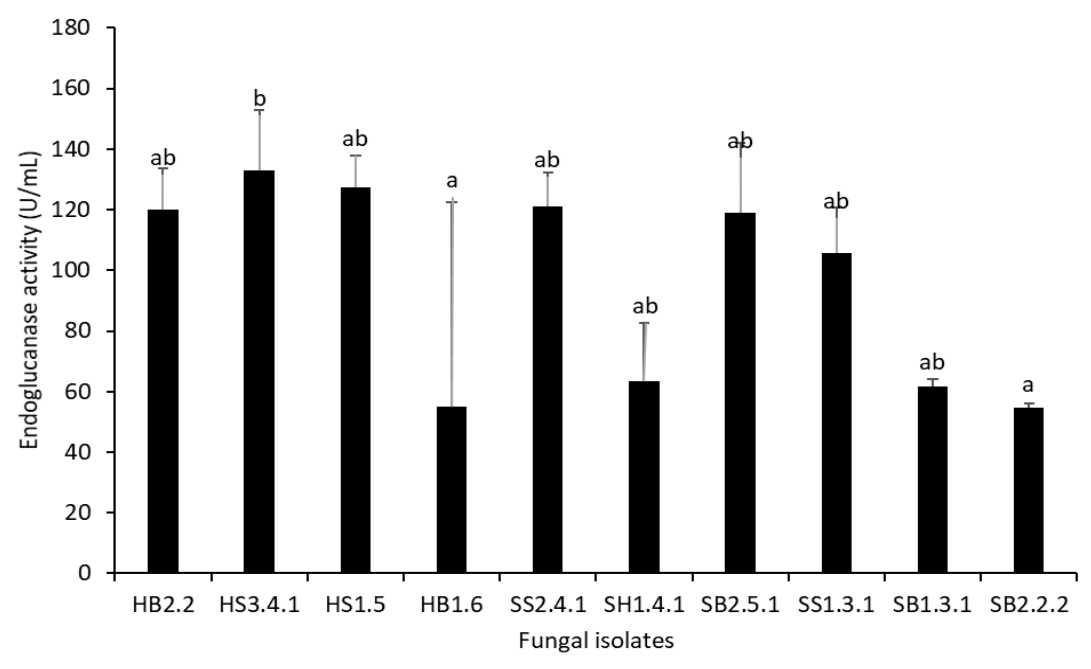

Figure 6. Endoglucanase activity of selected fungi isolates.

\section{Optimum pH and temperature for fungal cellulase activity}

Three fungal isolates (HS3.4.1, HS1.5, and SS2.4) which had high cellulase activity, were cultured at various $\mathrm{pH}$ and temperatures. The results showed that isolates HS3.4.1 and HS1.5 were able to grow at pH 2, 3, 4, and 5, and able to degrade cellulose (Figure 7). The isolates HS3.4.1 and HS1.5 were also able to grow at $35^{\circ} \mathrm{C}$ and capable of degrading cellulose. These isolates were collected from sapric peat. In sapric peat, almost all the remaining plant or cellulose had been degraded to into simple compounds.

Isolates HS3.4.1, HS1.5 and SS2.4.1 were able to degrade cellulose at $30^{\circ} \mathrm{C}$ ranged 1.4-2.1 U / mL (Figure 7). Isolates HS3.4.1 and HS1.5 were potential to degrade cellulose at $35^{\circ} \mathrm{C}$. At $40^{\circ} \mathrm{C}$ the three fungal isolates were unable to grow. The results showed that three isolates could grow and degrade cellulose at different $\mathrm{pHs}$, at $30^{\circ} \mathrm{C}$
(Figure 7). The ability to grow at a wide $\mathrm{pH}$ range may be caused by one enzyme, active at several $\mathrm{pH}$ values, or several enzymes with different optimal $\mathrm{pH}$ (Kunitake and Kobayashi 2017). Trichoderma and Penicillium have cellulolytic enzyme activity of $141.4 \mathrm{U} / \mathrm{mL}$ and $108.0 \mathrm{U} /$ $\mathrm{mL}$ at optimum $\mathrm{pH}$ and temperature of 4.0 and $30^{\circ} \mathrm{C}$ (Zhang et al. 2014). Most fungal endoglucanase activity has optimum at $\mathrm{pH} 4-6$. The relatively wide optimum $\mathrm{pH}$ of these three fungi showed that they could degrade cellulose in different $\mathrm{pH}$ environments (Figure 6). Penicillium possible grow in a wider range of soil $\mathrm{pH}(3-8)$ and may be influenced by other factors such as other cellulolytic fungi as competitor (Kornillowicz-Kowalska et al. 2003). P. citrinum grows optimally at $37^{\circ} \mathrm{C}$; other fungal species have a maximum growth temperature of $30^{\circ} \mathrm{C}$ (Houbraken et al. 2010). Most of the fungal endoglucanases have optimum activity at $\mathrm{pH} \quad 4-6$ (Fernandez et al. 2017). 


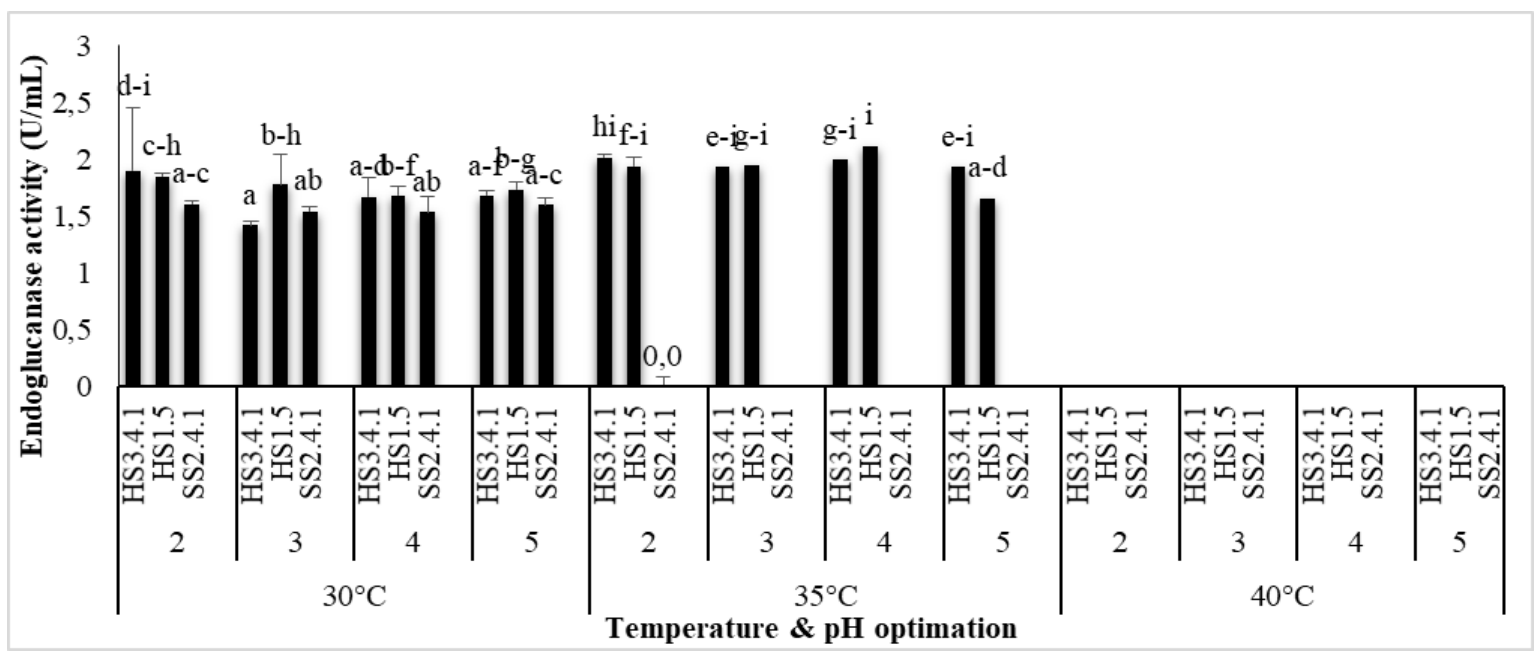

Figure 7. Cellulase enzyme activity (Endoglucanase) of selected fungi isolates cultured on $1 \% \mathrm{CMC}$ broth media at various $\mathrm{pH}$ and temperatures
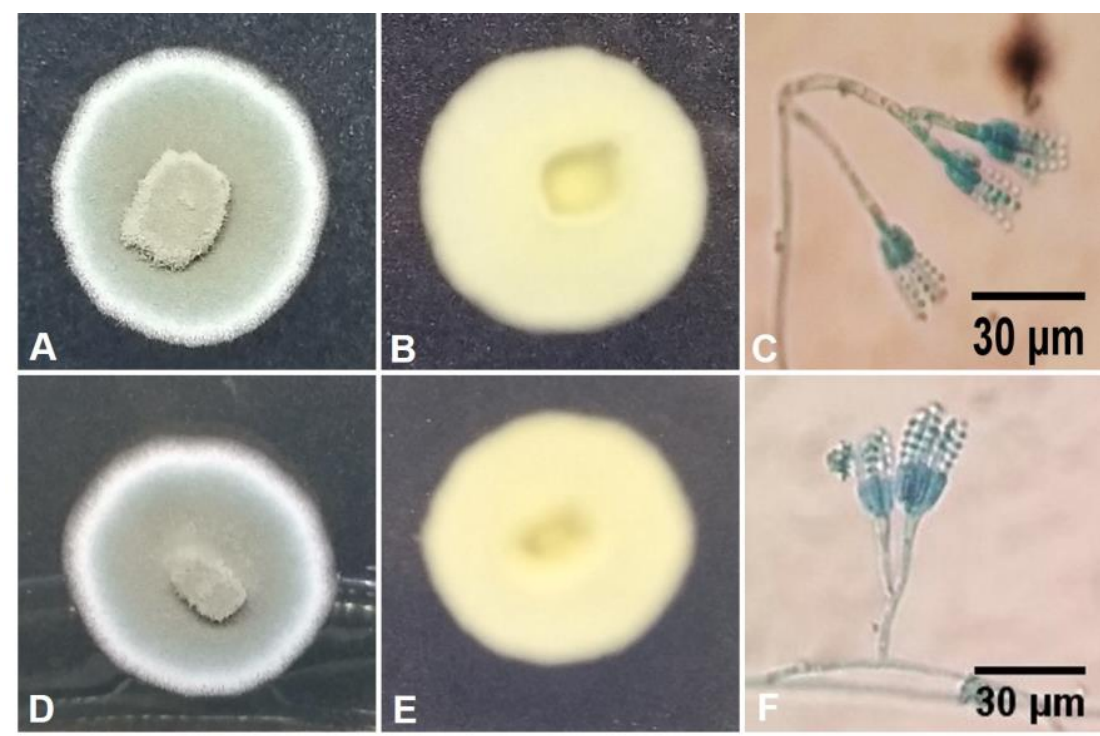

Figure 8. Morphological characters and microscopic structure (magnification (400 X) of HS3.4.1 and HS1.5 isolates. HS3.4.1 strain a) colonies viewed from above, b) colonies viewed from below c) hyphae structures, conidia; strain HS1.5 d) colonies viewed from above, e) colonies viewed from below f) hyphal and conidial structures

\section{Phylogenetic tree of selected fungi isolate}

Two isolates (HS3.4.1 and HS1.5) have morphological characters as follows: colony size $(27-28 \mathrm{~mm})$, filamentous colony shape, flat colony surface, having concentric lines, white pigmentation, inherent dry texture, optical features greyish green, white edges, and the edge of the colony thoroughly (Figure 8).

The HS3.4.1 and HS1.5 isolates were identified phylogenetically. The results showed that the two isolates belong to Penicillium citrinum based on the ITS sequence (Figure 9). Penicillium citrinum has a vertical terminal metulae with small conidia $(2-3 \mu \mathrm{m})$, sharing symmetrical biverticillate conidiophores with occasional additional branches. Sporulation on PDAs with bluish-gray conidia and reversing yellow. Conidiophores arising from aerial hyphae, predominantly irregularly biverticillate. Penicillium citrinum is a filamentous fungus common in nature (tropical), and it is found in various soil substrates, tropical cereals, spices, and indoor environments (Samson et al. 2004). P. citrinum produced citrinin mycotoxins consistently (Syrchin et al. 2015), and several other electrolytes, such as tanzowaic A acid, quinolactacins, quinocitrinine, asteric acids, and compactins (Syrchin et al. 2015; Mahishi et al. 2014). P. citrinum also interacts with plant roots. Therefore, it is very beneficial because the fungus produced gibberellins, to increase stem growth (Fernandez et al. 2017). The most common fungi genera were Aspergillus, Penicillium, Chaetomium, and Trichophyton, most of which can degrade cellulose (Arenas-Castro et al. 2016). 


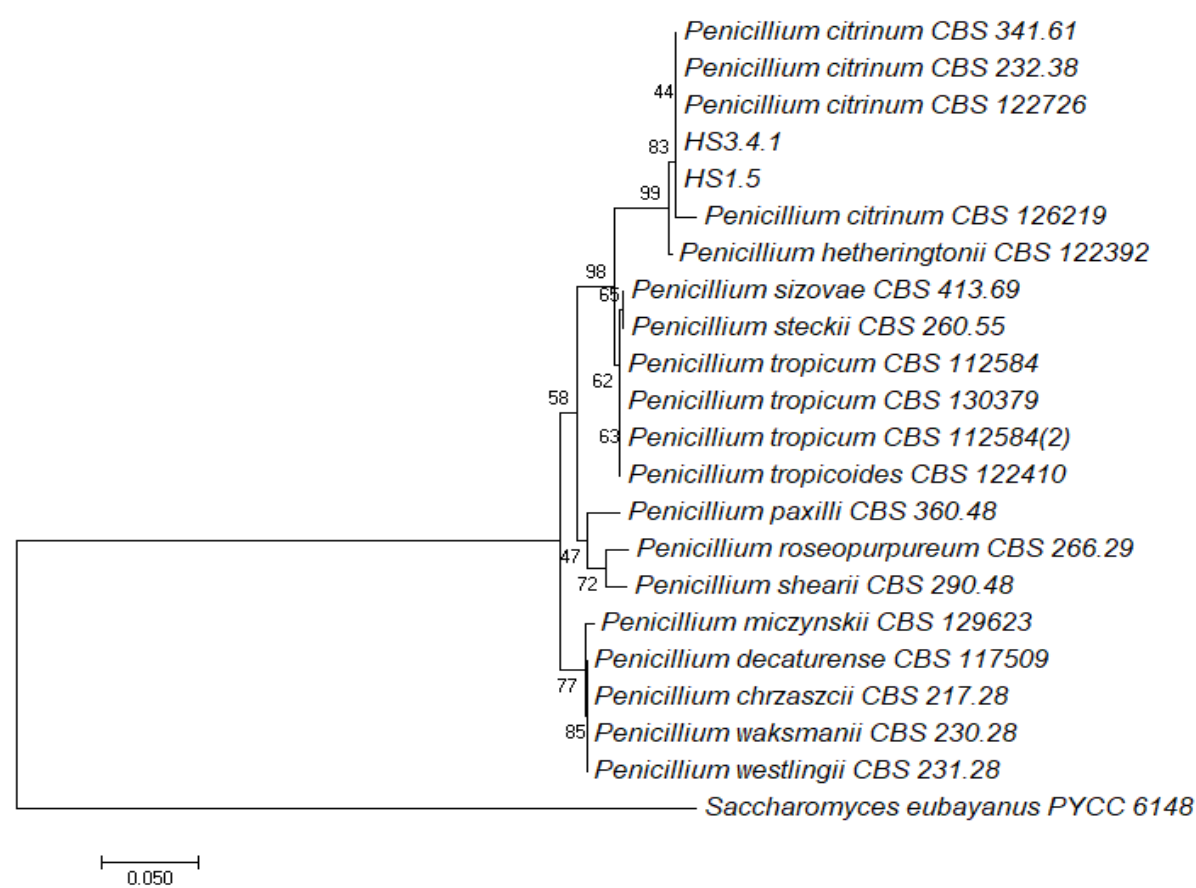

Figure 9. Neighbor-joining phylogenetic tree of HS3.4.1, HS1.5 and reference strain types based on ITS region of DNA sequences, with, Tamura-Nei algorithms of 1000 bootstrap replicates

In conclusion, the density of cellulolytic fungi in secondary forest at the fibric, hemic, and sapric peat were $3.2 \times 10^{3}, 4.6 \times 10^{3}$, and $5.6 \times 10^{3} \mathrm{cfu} / \mathrm{g}$, respectively. The cellulolytic fungi density in the shrubs/peat and palm oil area were $5.6 \times 10^{4}, 3.9 \times 10^{5}$, and $4.7 \times 10^{4} \mathrm{cfu} / \mathrm{g}$, respectively. Fifteen fungal isolates could degrade cellulose. The isolates $\mathrm{HS}_{1}, \mathrm{HS}_{3} .4 .1, \mathrm{SB}_{2} .2, \mathrm{SS}_{2} .2$, and $\mathrm{SH}_{1} .4$ had high cellulase activity that indicated by clear zone diameter of 20-25 mm. The isolates HS3.4.1, HS1.5, and SS2.4.1 cellulase enzyme activity at $132.16,127.3$, and $121 \mathrm{U} / \mathrm{mL}$, respectively. The HS3.4.1 and HS1.5 isolates

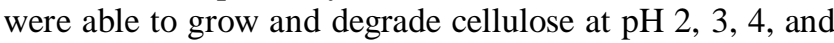
5 and at temperatures $30^{\circ} \mathrm{C}$ and $35^{\circ} \mathrm{C}$. Based on the ITS sequence similarity, HS3.4.1 and HS1.5 closely related to Penicillium citrinum. Indigenous fungi of peat soil of various levels of maturity can degrade high cellulose, capable of decomposing or reducing organic $\mathrm{C}$. The fungus can grow at an acidic $\mathrm{pH}$ of about $3-4$, a high temperature of $35^{\circ} \mathrm{C}$. This fungus can be used as a biofertilizer candidate on peat soils, especially fibric peat with high fiber content and low in nutrients. The cellulases secreted by these fungi can be developed commercially with further research.

\section{ACKNOWLEDGEMENTS}

The authors thank Brawijaya University, Malang, Indonsia and Tanjungpura University, Pontianak, Indonesia for supporting this research

\section{REFERENCES}

1st BASE. 2015. Universal Primers Offered. http//base-asia.com/dnasequencing-services/universal-primers-offered. Accessed May 8, 2017.

Agus F, Hairiah K, Mulyani A. 2011. Pengukuran Cadangan Karbon Tanah Gambut [Peat Soil Carbon Reserve Measurement]. Balai Besar Penelitian dan Pengembangan Sumberdaya Lahan Pertanian, Bogor. [Indonesian]

Arenas-Castro H, Muñoz-Gomez SA, Uribe-Acosta M, Castaño-Castaño L, Lizarazo-Medina, P.X. 2016. Richness, cellulolytic activity, and fungicide susceptibility of fungi from a bird biological collection. Acta Biol Colomb 21 (1): 167-173. DOI: 10.15446/abc.v21n1.49240

Atekan A, Nuraini Y, Handayanto E, Syekhfani S. 2014. The potential of phosphate solubilizing bacteria isolated from sugarcane wastes for solubilizing phosphate. J Degraded Mining Lands Manag 1 (4): 175182. DOI: $10.15243 / \mathrm{jdmlm} .2014 .014 .175$

Bahrami A, Emadolin I, Atashi MR, Bork HR. 2010. Land-use change and soil degradation: A case study, North of Iran. Agriculture and Biol J North Am 1 (4): 600-605.

Baldani JI, Reis VM, Videira SS, Boddey LH, Baldani VLD. 2014. The Art of isolating nitrogen-fixing bacteria from non-leguminous plants using $\mathrm{N}$-free semi-solid media: a practical guide for microbiologist. Plant Soil 384 (1-2): 413-431. DOI: 10.1007/s11104-014-2186-6

Baldrian P, Vorıskova J, Dobiasova P, Merhautova V, Lisa L, Valaskova V. 2011. Production of extracellular enzymes and degradation of biopolymers by saprotrophic microfungi from the upper layers of forest soil. Plant Soil 338 (1-2): 111-125. DOI: 10.1007/s11104-0100324-3

Behera BC, Parida S, Dutta SK, Thatoi HN. 2014. Isolation and identification of cellulose degrading bacteria from mangrove soil of Mahanadi river delta and their cellulase production ability. American J Microbiol Res 2 (1): 41-46. DOI: 10.12691/ajmr-2-1-6

Doolotkeldieva TD, Bobusheva ST. 2011. Screening of wild-type fungal isolates for cellulolytic activity. Microbiol Insights 4: MBI.26418. DOI: $10.4137 / \mathrm{mbi} . \mathrm{s} 6418$

Elliott DR, Caporn SJM, Nwaishi F, Nilsson RH, Sen R. 2015. Bacterial and fungal communities in degraded ombrotrophic peatland undergoing natural and managed re-vegetation. PLoS ONE 10 (5): eo124726. DOI: 10.1371/journal.pone.0124726 
Fernandez RD, Bulacio N, Alvarez A, Pajot H, Aragon R. 2017. Fungal decomposers of leaf litter from an invaded and native mountain forest of NW Argentina. Antonie van Leeuwenhoek 110 (9): 1207-1218. DOI: $10.1007 / \mathrm{s} 10482-017-0893-8$

Houbraken JAMP, Frisvad JC, Samson RA. 2010. Taxonomy of Penicillium citrinum and related species. Fungal Divers 44 (1): 117 133. DOI: $10.1007 / \mathrm{s} 13225-010-0047-\mathrm{Z}$

Kjoller A, Struwe S. 1982. Microfungi in ecosystems: Fungal occurrence and activity in litter and soil. Oikos 39 (3): 391-422. DOI $10.2307 / 3544690$

Kolli R, Asi E, Tonutare T, Astover A, Szajdak L, Tamm I. 2016. Fabric and properties of mineral soils underlying a shallow peat mantle in Estonia. Quat Int 418: 84-93. DOI: 10.1016/j.quaint.2015.08.045

Kornillowicz-Kowalska T, Iglik H, Wojdylo B. 2003. Correlation between the abundance of cellulolitic fungi and selected soil properties. Acta Mycol 38 (1-2): 161-172. DOI: 10.5586/am.2003.017

Kunitake E, Kobayashi T. 2017. Conservation and diversity of the regulators of cellulolytic enzyme genes in Ascomycete fungi. Curr Genet 63 (6): 951-958. DOI: 10.1007/s00294-017-0695-6

Lynd LR, Weimer PJ, van Zyl WH, Pretorius IS. 2002. Microbial cellulose utilization: Fundamentals and biotechnology. Microbiol Mol Biol Rev 66 (4): 506-577. DOI: 10.1128/mmbr.66.4.739.2002

Mahishi PK, Tiwari KL, Jadhav SK. 2014. Physiochemical and microbial studies of paper mill effluent, Raipur (Chhattisgarh), India. Banat's J Biotechnol V (9): 57-62. DOI: 10.7904/2068-4738-v(09)-57

Nurulita Y, Adetutu EM, Kadali KK, Shahsavari E, Zul D, Taha M, Ball AS. 2016. Assessment of the influence of oil palm and rubbe plantations in tropical peat swamp soils using microbial diversity and activity analysis. J Agric Chem Environ 5 (2): 53-65. DOI: 10.4236/jacen.2016.52006

Osono T. 2005. Colonization and succession of fungi during decomposition of Swida controversa leaf litter. Mycologia 97 (3): 589-597. DOI: 10.1080/15572536.2006.11832789

Osono T, Ishii Y, Takeda H, Seramethakun T, Khamyong S, To-Anun C, Hirose D, Tokumasu S, Kakishima M. 2009. Fungal succession and lignin decomposition on Shorea obtusa leaves in a tropical seasonal forest in northern Thailand. Fungal Divers 36: 101-119. DOI: 10.1.1.465.2471

Ritung S, Wahyunto W, Nugroho K, Sukarman S, Hikmatullah H, Suparto, Tafakresnanto C. 2011. Peta Lahan Gambut Indonesia Skala 1:250.000 [Map of Indonesian Peatlands Scale 1: 250,000]. BBSDLP, Bogor, Indonesia. [Indonesian]

Samson RA, Frisvad JC. 2004. Penicillium subgenus Penicillium: New taxonomic schemes and mycotoxins and other extrolites. Stud Mycol 49 (49): 1-260.
Saragih SD. 2009. Types of fungi at some level of peat maturity. [Thesis]. University of North Sumatra, Medan. [Indonesian]

Schropfer SB, Bottene MK, Blanchin L, Robinson LC, de Lima V, Jahno VD, da Silva Barud H Robeiro SJL. 2015. Biodegradation evaluation of bacterial cellulose, vegetable cellulose and poly (3hydroxybutyrate) in soil. Polimeros 25 (2): 154-160. DOI: 10.1590/0104-1428.1712

Sumawinata B, Djajakirana G, Handayani L. 2015. Assessment of physical, chemical and biological properties of peat soils. IPN Toolbox, Jakarta. [Indonesian]

Syrchin SO, Kharkevych OS, Pavlychenko AK, Yurieva OM, Nakonechna LT, Nekleva YS, Kurchenko IM. 2015. Extracellular cellulolytic complexes production by microscopic fungi. Biotechnol Acta 8 (5): 78-85. DOI: 10.15407/biotech8.05.078

Tonks AJ, Aplin P, Beriro DJ, Cooper H, Evers S, Vane CH, Sjogersten S. 2017. Impacts of conversion of tropical peat swamp forest to oil palm plantation on peat organic chemistry, physical properties and carbon stock. Geoderma 289 (1): 36-45. DOI: 10.1016/j.geoderma.2016.11.018

Voriskova J, Baldrian P. 2013. Fungal community on decomposing leaf litter undergoes rapid successional changes. ISME J 7 (3): 477-486. DOI: $10.1038 /$ ismej.2012.116

Wahyunto W. 2015. Peatlands in Indonesia. Term/definition, classification, extent, distribution, updating of spatial data on peatlands. IPN Toolbox, Jakarta. [Indonesian]

Wahyunto W, Supriatna W and Agus F. 2010. Land use change and recommendation for sustainable development of peatland for agriculture: Case study at Kubu raya and Pontianak Districts, West Kalimantan, Indonesia. Indones J Agric Sc 11 (1): 32-40. DOI: 10.21082/ijas.v11n1.2010.32-40

Wilson DB. 2011. Microbial diversity of cellulose hydrolysis. Curr Opin Microbiol 14 (3): 259-263. DOI: 10.1016/j.mib.2011.04.004

Yin LJ, Lin HH, Xiao ZR. 2010. Purification and characterization of a cellulose from Bacillus subtilis YJI. J Mar Sci Technol 18 (3): 466471.

Zhang P, Tian X, He X, Song F, Ren L, Jiang P. 2008. Effect of litter quality on its decomposition in broadleaf and coniferous forest. Eur $\mathrm{J}$ Soil Biol 44 (4): 392-399. DOI: 10.1016/j.ejsobi.2008.04.005

Zhang Z, Liu JL, Lan JY, Duan CJ, Ma QS, Feng JX. 2014. Predominance of Trichoderma and Penicillium in cellulolytic aerobic filamentous fungi from subtropical and tropical forests in China, and their use in finding highly efficient $\beta$-glucosidase. Biotechnol Biofuels 7 (1): 107. DOI: $10.1186 / 1754-6834-7-107$ 